\title{
Leaving Country for Living: Household Level Welfare Assessment from the Destination Preference Lens in Bangladesh
}

\author{
Mashrura Kabir Shaeba ${ }^{1}$, Fariha Farjana ${ }^{2} \&$ Subrata Kumar Datta ${ }^{1}$ \\ ${ }^{1}$ Graduate of Economics Discipline, Khulna University, Khulna, Bangladesh \\ ${ }^{2}$ Assistant Professor, Economics Discipline, Khulna University, Khulna, Bangladesh \\ Correspondence: Fariha Farjana, Assistant Professor, Economics Discipline, Khulna University, Khulna, \\ Bangladesh. Tel: 88-017-2623-8628. E-mail: fariha_farjana@yahoo.com
}

Received: February 20, 2020

Accepted: March 23, 2020

Online Published: March 30, 2020

doi:10.5539/ijef.v12n5p106

URL: https://doi.org/10.5539/ijef.v12n5p106

\begin{abstract}
Down memory lane of the economy of Bangladesh, international migration has been a pillar to the economy. Firstly, the study deals with the factors affecting destination preference of the migrant-sending household and then it tries to screne out the impact of international migration on the household welfare from the lens of diversified destination preferences. Considering sample size of 3782 household, the study conducted the entire research with the secondary data of Household Income and Expenditure Survey Bangladesh, 2016. Sorting the migrated countries among seven regions, Multinomial Logistic Regression has been used to find out the determinants behind migrants' destination preferences. Additionally, to measure the household welfare based on migrant's destination preference, the Ordinary Least Squares regression model and Quantile regression model have been used. Therefore, the result exhibits that migrant characteristic like age, gender, years of schooling, and household characteristics like heads' age, sex, schooling year, region, and earning status plays a significant role in deciding the migration destination. It is also evident that economic and subjective welfare varies among the households for sending migrants in different regions. Total expenditure and wealth index decrease to the households who send migrants to South-East Asia rather than Middle-East. The wealth score is higher for the households who send migrants to Europe, North-America, and Oceania over Middle-East. Subjective welfare index also varies among the household based on choosing migration destination. Therefore, it can be concluded that destination preference affects the economic and subjective welfare of the household.
\end{abstract}

Keywords: international migration, welfare, quantile regression, destination preference

\section{Introduction}

International migration holds a long history of diversity and has a significant influence on the socio-economic and demographic condition on the migrant sending and receiving country. Though many nations consider it as a temporary situation but in general, it is constructing a structural and dynamic phenomenon (Hugo, 2005). The practice of migration in Bangladesh is also very common and discussion worthy as the remittance from it contributes to the economy of Bangladesh. It has turned out as an important livelihood strategy irrespective of the poor or well off households. The choice of destination depends on the economic and social status of the migrants (Siddiqui, 2003). Bangladesh is the eighth largest remittance recipient country in the world (World Bank, 2010). Certainly, the inflow of remittance through migration blow a breeze to the development of both social, and economic aspects of Bangladesh which eventually helps to mitigate poverty and upholds the living standard of the migrant household. Bureau of Manpower, Employment and Training (BMET) shows that 48 percent of the migrant workers from Bangladesh are low-skilled, 15 percent semi-skilled, 33 percent skilled, and only 2 percent are professionals (IOM, 2017). Therefore, BMET is continuously arranging training and also providing certificate to the graduates as it can help the migrant workers who leave home for their livelihood.

Day by day the number of migration is increasing as the country is trying to lessen down the official regulations and also establishing a good bilateral and multilateral relation with the countries. Different country has different laws and earning rules for the migrants. Therefore, the wellbeing may vary in terms of the country where they migrate. In this circumstance, it is necessary to look over the reasons that affect the household choice for destination and analyze the effects of the migrant's household economic condition in respect to their destination of migration. Some of the studies have shown that the migration has made a drastic change to the socio-economic and 
living of standard of the migrant household (Pfau \& Giang, 2009). Countries like western and Europe have different earing standard than the middle-east countries. As most of the people go middle-east with low skilled jobs so their earning and living standard will be different than the people who migrate with skilled jobs to the developed countries. Based on this point, this study will evaluate the impact of the migrant household's welfare from their destination preference lens. The objective of the study is to evaluate the impact of migration on household welfare based on the deviation of destination preference.

In order to attain the objective of the study authors consider the following research questions.

a) What are the factors affecting the destination preference of the migrant sending household?

b) How destination preferences of the migrant affect the household welfare?

This study deals with the aspect of international migration of Bangladesh to find out its determinants and also to evaluate the impact of destination preference on the welfare of the households. Household welfare has been analyzed with two dimensions namely Economic and Subjective welfare. Since the study is focused on destination of the migrants, the destined countries are being arranged into some region for simplifying the analysis. Therefore, the upcoming part of the paper first discusses empirical evidence of versatile scholars' research regarding factors affecting international migration and its aftermath, then the methodology part delineates well structured econometric model formulation based on support from literature, after that the data are analyzed and discussed. Finally, the paper presents the overall findings and concluding remarks.

\section{Literature Review}

Pellegrini and Fotheringham (2002) state that migration is an interdisciplinary field of study where it is a very crucial point for economists, sociologists, demographers, etc. to understand the cause and consequence and pattern of moving of the individuals from one place to another. Basically, at first, the study tries to answer 'why' and 'where' the people migrate, and then it evaluates the impact of different destination preference on household welfare from the economic and subjective lens. Greenwood (1975) has tried to figure out the determinants of migration and also the consequence of it. According to Siddiqui (2003) from Bangladesh context two types of voluntary international migration is detected, i.e. people mostly migrate to the industrialized west and the other to Middle Eastern and Southeast Asian countries. In the case of the industrialized west, migrants often choose permanent migration however, migrants of the Middle-East choose temporary migration for livelihood from Bangladesh. Meanwhile, the study of Mahmud (2016) says that the remittance of the Bangladeshi migrants varies with the preferred destination countries as the policy, regulation varies from countries to countries. Moreover, the remittance difference matters for the destination state's regulation of the labor market and permanent settlement shape migrants' remitting practices. Orozco (2010) discovered a diversified scenario of migration and remittance of Bangladesh. Firstly, the study found that more than 70 percent of the migrants prefer to move gulf countries. Secondly, 90 percent of the households received remittance from their migrant relatives. According to Mora and Taylor (2006) education does not affect international migration but does for the internal migration. On the other hand, the family contact with the migrated country has a positive effect on household expenditure as same as the household wealth in the case of the international migration of Mexico. Furthermore, different household head characteristics like age, education, marital status positively affect the decision to choose Gulf countries for migration. Whereas, extended families trigger the decision to send the migrants in Malaysia (Regmi, 2014). Viet Cuong and Mont (2012) observed the impact of international migration on the household welfare and also tried to show the impact of remittances on the consumption pattern of the households. The study has taken shared expenditure of different section of expenditure to see whether those sections of expenditure vary for remittance inflow of household. Non-production and production expenditure were the two main section of expenditure of this study. However, Regmi (2014) has used the wealth index as a proxy variable to measure the life standard of the migrant household. The authors have also used the Principal Component Analysis (PCA) tool to construct the wealth index with various factors. According to the study of Amit and Riss (2014) most of the immigrants from North America to Israel do not feel to go back to their native country as long as they get the same living standard as in the origin country. Social networks, religious motive and also the work satisfaction of the immigrants in Israel make them stay as their households are also supportive. Therefore, the empirical evidence justify lots of the outcome can be considered as an indicator of welfare assessment i.e. consumption expenditure, productive and non-productive expenditure, wealth index etc. and the paper also tries to assess the overall welfare following the footprints of the scholars.

\section{Methodology}

The study used secondary data of HIES 2016, collected from Bangladesh Bureau of Statistics (BBS). The data has been collected through maintaining all the official procedures and regulations of the authority. According to 
the BBS, HIES 2016 was accomplished from April $1^{\text {st }}$, 2016 to March 31th, 2017. Except some of the minor changes, the survey was done according to the module of HIES 2010. Two different levels of stratification are used for the sampling design of HIES 2016, where the country is divided according to the division and further divided into Urban, Rural, and City corporation areas. A total of 48,080 households were chosen for the survey with the sampling formula using mean household consumption as the targeted variable. According to this study, households who have migrant members from Bangladesh to different countries are considered as our sample. Since this study is indulged in international migration, the study only dealt with 3,782 households as the sample.

\subsection{Empirical Analysis}

\subsubsection{Determinants of Destination Preference}

To determine the factors that affect the destination preference of the households' migrant-sending decision authors applied the multinomial logistic regression model following Fafchamps and Shilpi (2008). In this regard the countries have been categorized into seven major destinations, i.e. East Asia, South-East Asia, Africa, Middle-East, Europe, Oceania, and North-America. In this study, the base category is 'Middle-East'. Suppose, there are $\mathrm{k}^{\text {th }}$ predictors, i.e. $\mathrm{X}_{1}, \mathrm{X}_{2}, \mathrm{X}_{3}, \ldots, \mathrm{X}_{\mathrm{k}}$ (categorical and continuous) and the outcome categorical variable $\mathrm{Y}$ (destination preference) have $\mathrm{J}$ categories then the generalized form of the multinomial logit model is:

$$
\operatorname{logit}\left(Y_{j}\right)=\ln \left[\frac{P(Y=j \mid X)}{P(Y=J \mid X)}\right]=\beta_{j 0}+\beta_{j 1} X_{1}+\beta_{j 2} X_{2}+\cdots+\beta_{j k} X_{k}
$$

Here, in equation $1, “ \mathrm{j}=1,2, \ldots, \mathrm{J}-1$, and we have $\mathrm{J}-1$ logit equations. Here, each of them is a linear function that models the logarithm of probability as having response $\mathrm{j}$ to baseline category $\mathrm{J}$. All logits are defined relative to such a predetermined baseline category. It is important to point out that, because they are unordered, any of the J categories can be taken as the reference outcome (Milewska, 2017, p. 9)". The explanatory variables comprise migrant's characteristics, household characteristics, etc. Point to be noted that, the study has considered only households that have international migrants. It makes the model compatible to find out the factors that influence the destination preference of migrant sending households (Fafchamps \& Shilpi, 2008).

\subsubsection{Economic Welfare Assessment from Destination Preference Lens}

\section{a) Household expenditure pattern}

As an indicator of economic welfare, this study has chosen log expenditure per month as the dependent variable. OLS regression has been used for finding out the impact of migration decision and other factors on the economic condition of the migrants.

$$
Y_{j}=\alpha+\sum \beta_{j} X_{j}+\sum Y_{j} D_{j}+U_{j}
$$

$\mathrm{Y}_{\mathrm{j}}=$ Log expenditure per month of the household,

$\beta_{\mathrm{j}}=$ Vector of coefficients;

$\mathrm{D}_{\mathrm{j}}=$ Reference dummy variable for region, considering 'Middle-East' as the base category;

$\Upsilon_{\mathrm{j}}=$ Vector of coefficients;

$\mathrm{X}_{\mathrm{j}}$ Vector of explanatory variables;

$\mathrm{U}_{\mathrm{j}}=$ Error term.

Following Viet Cuong and Mont (2012) and Adams Jr and Cuecuecha (2010) to evaluate the overall impact of remittance on household welfare from destination preference lens authors segregated the household consumption expenditure pattern into two parts, i.e. food and non-food expenditure. After that the non-food expenditure of the households are again categorized into purchase of durable goods, insurance, purchase of property, expenditure on education and medical facilities.

\section{b) Household asset building capacity}

Besides evaluating the expenditure pattern of the households as a proxy of welfare, the paper also looks into the households' asset building capacity as another indicator of wellbeing. In this point, following Regmi (2014) wealth index is measured as a proxy of the living standard of the migrants.

$$
W_{i}=\sum_{k} \alpha_{k}\left(\frac{x_{i k-\bar{x}_{k}}}{\sigma_{k}}\right)
$$

Here, in equation 3, $x_{i k}$ is the value of asset $k$ for household $i, \overline{x_{k}}$ is the sample mean, $\sigma_{k}$ is the sample standard deviation and $\alpha_{k}$ represents the weight for each variable $x_{i k}$ for the first principal component that is calculated 
using PCA (Regmi, 2014). Primary analysis can be done based on PCA using a core set of household assets and characteristics all coded as binary indicator variables (Chasekwa et al., 2018). This study also follows the same procedure.

In this regard, the paper applies quantile regression. Basically, it is very close to OLS regression methods, but quantile regression presents associations at a specified quantile of the conditional dependent variable rather than focusing on associations at the mean (Lozano \& Steinberger, 2012). Therefore, quantile regressions are of huge importance when the relationship between the explanatory and dependent variables is not constant across the distribution (Lozano \& Steinberger, 2012). In the study of Serino and Kim (2011), quantile regression has been used to measure the impact of international remittance on poverty where the outcome of poverty can be identified in quantile. Authors also adopt the method in this analysis by using wealth index as a proxy of asset building capacity of the household which also justifies household level economic welfare. Therefore, this method helped to unveil the impact of destination preference on wealth across the four quantiles rather than focusing only on the mean value (Koenker \& Regression, 2005). This study is using the quantile regression following the model Serino and Kim (2011).

$$
W_{i}=\left(Z_{i}\right) \beta_{\theta}+u_{\theta i}
$$

With the quantile regression model,

$$
\operatorname{Quant}_{\theta}\left(W_{i} \mid\left(Z_{i}\right)\right)=\left(Z_{i}\right) \beta_{\theta}
$$

Here,

Quant $_{\theta}\left(W_{i} \mid\left(Z_{i}\right)\right)=$ the $\theta_{\text {th }}$ conditional quantile of Wealth index $(W)$;

$(Z)=$ Set of explanatory variable and subscript $\mathrm{i}=1,2 \ldots \mathrm{n}$ indexes the Household;

$\beta_{\theta}=$ Vector of coefficient;

$\mathrm{U}_{\theta \mathrm{i}=}$ error term.

c) Subjective Welfare

For analyzing the household welfare looking into the economic welfare in not enough, considering this aspect, the paper also focuses on the subjective welfare of the migrant sending households from the destination preference lens. Five indicators are chosen for measuring the subjective welfare index of the household. The indicators are demonstrated in Table 1.

Table1. Indicators of the subjective welfare

\begin{tabular}{lr}
\hline Indicator & Response \\
\hline Making some extra after meeting needs & Yes/No \\
Social safety nets & Yes/No \\
Adequate rooms for living & Yes/No \\
Good sanitization facility & Yes/No \\
Adequate pure drinking water & Yes/No \\
\hline
\end{tabular}

Authors' compilation based on data HIES 2016.

*The value of the index holds ranges from 0 to 1 .

After measuring the subjective welfare from the index, it is used as the dependent variable to analyze how the variation of destination choice of the household causes variation in subjective welfare. Since the dependent variable is continuous in nature OSL model is applied for further analysis.

$$
S_{i}=\alpha+\sum \beta_{i} X_{i}+\sum Y_{i} D_{i}+U_{i}
$$

$S_{\mathrm{i}}=$ Subjective welfare index;

$\mathrm{X}_{\mathrm{i}}=$ Represents the vector of explanatory variables;

$\beta_{i}=$ Vector of regression coefficients;

$D_{i}=$ Dummy variable for region, considering 'Middle-East' as the base category;

$Y_{i}=$ Vector of coefficient;

$U_{\mathrm{i}}=$ Error term. 


\subsection{List of Variables}

All of the variables with their corresponding measurement unit and supported literature are presented in Table 2 .

Table 2. List of variable

\begin{tabular}{|c|c|c|}
\hline Variable & Unit of Measurement & Related Literature \\
\hline \multicolumn{3}{|c|}{ Dependent Variables } \\
\hline Destination choice of migration & $\begin{array}{r}\text { Reference Dummy (Base category= } \\
\text { 'Middle-East') }\end{array}$ & $\begin{array}{r}\text { (Regmi, 2014), (Fafchamps and Shilpi, } \\
2008)\end{array}$ \\
\hline Ln (Expenditure) & In BDT per month & (Viet Cuong and Mont, 2012) \\
\hline Wealth Index & In Number & $\begin{array}{r}(\text { Regmi, 2014) } \\
(\text { Mora, et al., 2005) }\end{array}$ \\
\hline Subjective Index & In Numbers (Value 0 to 1 ) & $\begin{array}{r}\text { (de Brauw, Mueller, and Woldehanna, } \\
\text { 2013) }\end{array}$ \\
\hline \multicolumn{3}{|c|}{ Explanatory Variables } \\
\hline \multicolumn{3}{|l|}{ Migrant Characteristics } \\
\hline Age & In Number & (Mora, et al., 2005) \\
\hline Sex & Dummy (Male=1, Female=0) & (Mora, et al., 2005) \\
\hline Education & Number of Schooling Year & (Raihan, et al., 2009) \\
\hline Migration Duration & In Number & Authors' compilation \\
\hline \multicolumn{3}{|l|}{ Household Characteristics } \\
\hline Age of Household Head & In Number & (Mora, et al., 2005) \\
\hline Sex of Household Head & Dummy $($ Male $=1$, Female $=0$ ) & $\begin{array}{r}\text { (Raihan, et al., 2009), } \\
\text { (Mora, et al., 2005) }\end{array}$ \\
\hline Education of Household Head & Number of Schooling Year & (Raihan, et al., 2009) \\
\hline Household Size & In Number & $\begin{array}{r}\text { (Raihan, et al., 2009) } \\
\text { (Mora, et al., 2005) }\end{array}$ \\
\hline Migrant sending destination & Region Dummy & Authors' compilation \\
\hline Number of member less than 10 years & In Number & Authors' compilation \\
\hline Ln (Income) & In BDT per month & Authors' compilation \\
\hline International Remittance & BDT per month & (Viet Cuong and Mont, 2012) \\
\hline Frequency of Sending Remittance & In number & Authors' compilation \\
\hline Agricultural Land & (In Hectares) & (Viet Cuong and Mont, 2012) \\
\hline Dwelling Land & (In Hectares) & Authors' compilation \\
\hline Non-cultivate Land & (In Hectares) & Authors' compilation \\
\hline Total Operative Land & (In Hectares) & Authors' compilation \\
\hline
\end{tabular}

Authors' compilation based on data HIES 2016.

\section{Results and Discussion}

\subsection{Factors Affecting Destination Preference}

Destination preference for migration varies across several household characteristics and individual factors of the migrants. This study concerns to identify which factors trigger the household to prefer a certain region for migration. Here, multinomial logistic regression is applied to oozing out the determinants of the destination preference of the migrant households. With seven categories of region, Middle-East as reference category the model found the following outcome.

In Table 3 the Multinomial Logistic Regression model predicts that gender of the migrant is a significant factor since male migrants are more likely to migrate than female in South-East Asia rather than in Middle-East with 1 percent significant level. However, compared to male, female have 0.2145 percent more probability to migrate in Europe and 0.0129 percent more for North-America than Middle-East. This could be the reason that county like Europe and North-America provide safe job environment and better facility for the working population.

Meanwhile, the age of the migrant also shows expected results, an increase of age of the migrant makes less probability to choose to migrate in East-Asia and South-East Asia but with one year increase of migrant age has 0.0005 percent more probability to migrate in North-America than Middle-East. This is because people want better facilities to live, and work at their old age. 
Table 3. Multinomial logistic regression model

\begin{tabular}{lllllll}
\hline Explanatory Variables & East-Asia & South-East Asia & Africa & Europe & North America & Oceania \\
\hline Sex (Migrant) Male=1, & -0.0165 & $0.1721^{* * *}$ & 0.0097 & $-0.2145^{* * *}$ & $-0.0129^{* *}$ & -0.0102 \\
Female=0 & $(0.0239)$ & $(0.0262)$ & $(0.0020)$ & $(0.0532)$ & $(0.0113)$ & $(0.0145)$ \\
Sex (Household Head) & -0.0104 & -0.0066 & -0.0053 & $0.0575^{* * *}$ & 0.0047 & -0.0088 \\
Male=1, Female=0 & $(0.0117)$ & $(0.0289)$ & $(0.0065)$ & $(0.0154)$ & $(0.0043)$ & $(0.0071)$ \\
Migrant Age & $-0.0008^{* *}$ & $-0.0054 * * *$ & -0.0003 & 0.0007 & $0.0005^{* * *}$ & -0.0001 \\
& $(0.0004)$ & $(0.0010)$ & $(0.0002)$ & $(0.0005)$ & $(0.0002)$ & $(0.0001)$ \\
Education of migrant (Years & -0.0005 & -0.0048 & $0.0021^{* * *}$ & $0.0107 * * *$ & $0.0028^{* * *}$ & $0.0010^{* * *}$ \\
of Schooling) & $(0.0010)$ & $(0.0026)$ & $(0.0007)$ & $(0.0015)$ & $(0.0006)$ & $(0.0004)$ \\
Area (Rural=1,urban=0) & 0.0058 & $-0.0521^{* * *}$ & 0.0027 & -0.0044 & $-0.0089^{* *}$ & 0.0053 \\
& $(0.0073)$ & $(0.0206)$ & $(0.0041)$ & $(0.0110)$ & $(0.0043)$ & $(0.0024)$ \\
Household size & 0.0008 & $-0.0148 * * *$ & $-0.0018 *$ & $0.0036^{*}$ & $0.0013 * *$ & 0.0000 \\
& $(0.0013)$ & $(0.0042)$ & $(0.0012)$ & $(0.0017)$ & $(0.0005)$ & $(0.0001)$ \\
Head education & -0.0001 & $-0.0052^{* *}$ & $0.0013 * *$ & -0.0004 & 0.0001 & $0.0004 *$ \\
Head age & $(0.0009)$ & $(0.0024)$ & $(0.0006)$ & $(0.0013)$ & $(0.0005)$ & $(0.0002)$ \\
& 0.0003 & -0.0002 & $0.0003 * *$ & 0.0001 & $0.0003 *$ & 0.0000 \\
Head Earner (Y=1,N=0) & $(0.0003)$ & $(0.0007)$ & $(0.0002)$ & $(0.0004)$ & $(0.0002)$ & $(0.0001)$ \\
& 0.0083 & $0.0845 * * *$ & -0.0025 & $-0.0325 *$ & $0.0131^{* * *}$ & 0.0030 \\
Agricultural Land (In & $(0.0102)$ & $(0.0267)$ & $(0.0049)$ & $(0.0117)$ & $(0.0053)$ & $(0.0034)$ \\
Hectares) & 0.0000 & -0.0172 & -0.0148 & -0.0004 & -0.0045 & $0.0018^{*}$ \\
Dwelling Land (In Hectares) & $(0.0071)$ & $(0.0208)$ & $(0.0101)$ & $(0.0097)$ & $(0.0048)$ & $(0.0010)$ \\
Constant & 0.0039 & -0.1639 & 0.0022 & 0.0446 & -0.0573 & 0.0047 \\
\hline Observations & $(0.0247)$ & $(0.1145)$ & $(0.0134)$ & $(0.0247)$ & $(0.0374)$ & $(0.0026)$ \\
\hline
\end{tabular}

Authors' compilation based on data HIES 2016.

Note. Standard error in the parentheses. $* * * \mathrm{P}<0.01$, $* * \mathrm{P}<0.05, \mathrm{P}<0.1$.

In Table 3 the data delineates that if the schooling year increases of the migrant then the probability of migrating Africa is 0.0021 percent more, for European countries it is 0.0107 percent more, 0.0028 percent more for North-American countries and 0.0010 percent more for countries of Oceania than Middle-East countries with 1 percent significance level. It is obvious to choose developed countries mostly when the members of the household become more educated as they can pursue white collar job.

The household size seemed to serve a significant and versatile impact on the migrant sending household to choose the region for international migration. If the household size increases by one person then the probability of migrating to countries of South-East Asia decreases by 0.0148 percent than the countries of Middle-East. Larger the household size, higher the economic burden and lesser the scope to educate the children. Hence, they prefer to send their member in the countries of Middle-East as workers to secure household income.

Additionally, when the head of the migrant-sending household earns, the probability of migrating towards countries of South-East Asia increase by 0.0845 percent more than countries of Middle-East compared to the non-earner household head. This result has similarity with choosing North-American countries as a migration destination. The result may be justified as, if the household head contributes (financially) to family tries to send their son/daughter to secure countries for better job opportunities. On the other hand, the non-earner heads have a higher economic burden so they try to send their members in those countries where it is cheaper to migrate. The data claims that the probability decreases by 0.00325 percent to migrate European countries than Middle-East countries with 10 percent level of significance.

Lastly, with the increase of one percent agricultural land of the household, the probability of migration increases by 0.0018 percent for countries of Oceania than Middle-East countries. It is natural if the household have enough asset and land, they try for better lifestyle, so they are more likely to prefer countries like Australia than Saudi Arabia to send household members for migration.

\subsection{Welfare Assessment from Destination Preference Lens}

The paper evaluates household level welfare of the migrants from two dimensions, i.e. Economic welfare and subjective welfare based on their destination preference. 


\section{a) Economic Welfare Assessment from the Dimension of Household Expenditure}

There are many economic factors to measure the welfare of the household. This study chooses household expenditure as an economic indicator to determine welfare. Along with this, the wealth index is also been chosen as the proxy of asset building capacity of the households that also portray economic welfare. Table 4 summarizes the impact of destination preference of the migrants on different sectors of household expenditure. By using the ordinary least square method this study examined the impact by running several models. The OLS result shows that increasing monthly remittance inflow increases the household total expenditure along with expenditure categories like food expenditure, non-food expenditure with a 1 percent level of significance. Obviously it provides a positive signal to the economic welfare of the migrants' household and the result is consistent with Adams Jr (1991).

Table 4. OLS regression models on economic welfare assessment

\begin{tabular}{|c|c|c|c|c|c|c|c|c|c|}
\hline \multirow{2}{*}{\multicolumn{2}{|c|}{$\begin{array}{l}\text { Explanatory } \\
\text { Variables }\end{array}$}} & \multirow{2}{*}{$\begin{array}{c}\text { Total } \\
\text { Expenditure } \\
\text { Model (1) } \\
\end{array}$} & \multirow{2}{*}{$\begin{array}{c}\text { Food } \\
\text { Expenditure } \\
\text { Model (2) } \\
\end{array}$} & \multirow{2}{*}{$\begin{array}{c}\text { Nonfood } \\
\text { Expenditure } \\
\text { Model (3) }\end{array}$} & \multicolumn{5}{|c|}{ Segregated Non-food Expenditure } \\
\hline & & & & & $\begin{array}{c}\text { Durable Goods } \\
\text { Model (4) }\end{array}$ & $\begin{array}{l}\text { Insurance } \\
\text { Model (5) }\end{array}$ & $\begin{array}{l}\text { Property } \\
\text { Model (6) }\end{array}$ & $\begin{array}{c}\text { Educational } \\
\text { Model (7) }\end{array}$ & $\begin{array}{r}\text { Medical } \\
\text { Model (8) }\end{array}$ \\
\hline \multirow{2}{*}{\multicolumn{2}{|c|}{$\begin{array}{l}\text { Ln(Ren } \\
\text { BDT) }\end{array}$}} & $0.149 * * *$ & $0.0365 * * *$ & $0.155^{* * *}$ & ** & $5 *$ & 0.0 & 0.06 & $0.0736 * * *$ \\
\hline & & $(0.0151)$ & $(0.0$ & $(0.0$ & $0.0348)$ & $(0.0570)$ & $(0.0742)$ & $(0.0224)$ & $(0.0182)$ \\
\hline \multirow{2}{*}{\multicolumn{2}{|c|}{ East-Asia }} & 208 & -0.1 & 0.0 & $311 * * *$ & 0.156 & 0.731 & $-0.329 * *$ & -0.155 \\
\hline & & $(0.0813)$ & $(0.0503)$ & $(0.0842)$ & $(0.1967)$ & $(0.5072)$ & $(0.4191)$ & $(0.1571)$ & $(0.1407)$ \\
\hline \multirow{2}{*}{\multicolumn{2}{|c|}{ South-East Asia }} & $-0.0649 * *$ & $-0.141 * * *$ & $-0.0558^{*}$ & $0.412 * * *$ & -0.299 & $-0.543 * *$ & 0.0668 & $-0.101 *$ \\
\hline & & $(0.0320)$ & $(0.0209)$ & $(0.0335)$ & $(0.1015)$ & $(0.2351)$ & $(0.3924)$ & $(0.0521)$ & $(0.0587)$ \\
\hline \multirow{8}{*}{ 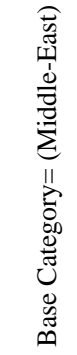 } & \multirow[t]{2}{*}{ Africa } & $0.330^{* *}$ & $0.346^{* * *}$ & $0.362 * * *$ & $0.796^{*}$ & 1.578 & -0.736 & $0.562 * *$ & 0.385 \\
\hline & & $(0.1044)$ & $(0.1053)$ & $(0.1095)$ & $(0.3278)$ & $(0.1908)$ & $(0.2817)$ & $(0.1699)$ & $(0.2653)$ \\
\hline & \multirow[t]{2}{*}{ Europe } & $0.278 * * *$ & 0.0414 & $0.299 * * *$ & 0.130 & 0.168 & -0.366 & $0.393 * * *$ & $0.242 * *$ \\
\hline & & $(0.0625)$ & $(0.0390)$ & $(0.0654)$ & $(0.2541)$ & $(0.3702)$ & $(0.8974)$ & $(0.1003)$ & $(0.1089)$ \\
\hline & \multirow[t]{2}{*}{ North-America } & 0.112 & $-0.176^{*}$ & 0.261 & 0.189 & -0.476 & -0.755 & $0.559^{*}$ & $0.901 * * *$ \\
\hline & & $(0.1893)$ & $(0.10$ & $(0.1456)$ & $(0.7186)$ & $(0.3847)$ & $(0.2924)$ & $(0.2291)$ & $(0.1887)$ \\
\hline & \multirow[t]{2}{*}{ Oceania } & $1.158 * * *$ & 0.0534 & $1.133 * * *$ & -0.0242 & 1.427 & & $1.477 * *$ & $1.281^{* *}$ \\
\hline & & $(0.1142)$ & $(0.26$ & $(0.1069)$ & (1.8903) & $(0.2370)$ & & & $(0.3786)$ \\
\hline \multirow{2}{*}{\multicolumn{2}{|c|}{ Household size }} & $0.104 * * *$ & $0.0998 * * *$ & $0.101 * * *$ & $0.0733^{* * * *}$ & 0.000613 & -0.00993 & $0.108 * * *$ & $0.113^{* * *}$ \\
\hline & & $(0.0100)$ & $(0.0078)$ & $(0.0106)$ & $(0.0335)$ & $(0.0453)$ & $(0.0389)$ & $(0.0147)$ & $(0.0168)$ \\
\hline \multirow{2}{*}{\multicolumn{2}{|c|}{$\begin{array}{l}\text { Household member } \\
\text { less than } 10 \text { years }\end{array}$}} & $-0.0457 * * *$ & -0.0105 & $-0.0455^{* * *}$ & -0.0333 & -0.0495 & 0.109 & $-0.204^{* * *}$ & 0.00686 \\
\hline & & $(0.0182)$ & $(0.0078)$ & $(0.0190)$ & $(0.0606)$ & $(0.0930)$ & $(0.1387)$ & & $(0.0315)$ \\
\hline \multirow{4}{*}{ 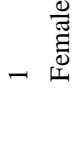 } & \multirow{4}{*}{$\begin{array}{l}\text { Gender of } \\
\text { household head } \\
\text { Age of } \\
\text { household head }\end{array}$} & $0.0937 * *$ & $0.145 * * *$ & $0.0805^{*}$ & $0.386^{* *}$ & -0.348 & 0.5 & $-0.294 * * *$ & $0.373^{* * *}$ \\
\hline & & $(0.0426)$ & $(0.0305)$ & $(0.0444)$ & $(0.1610)$ & $(0.2773)$ & $(0.2622)$ & $(0.0$ & $(0.0815)$ \\
\hline & & 0.000863 & $0.00598 * * *$ & 0.000108 & -0.00223 & -0.00715 & -0.00188 & 0.00257 & $0.0106^{* * *}$ \\
\hline & & $(0.0011)$ & $(0.00$ & $(0.00$ & & & & & \\
\hline \multirow{2}{*}{ 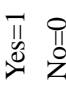 } & \multirow[t]{2}{*}{ Earning status } & -0.0262 & -0.0307 & -0.0363 & $-0.259 *$ & -0.179 & $-0.696^{* *}$ & 0.0768 & $-0.208 * * *$ \\
\hline & & $(0.0384)$ & $(0.0271)$ & $(0.0397)$ & $(0.1419)$ & $(0.2361)$ & $(0.3114)$ & $(0.0685)$ & $(0.0706)$ \\
\hline \multirow{5}{*}{ 一 莡 } & \multirow{2}{*}{ Origin } & $-0.280 * * *$ & $0.101 * * *$ & $-0.311 * * *$ & $-0.247 * *$ & 0.125 & $0.585^{* *}$ & $-0.329 * * *$ & 0.000688 \\
\hline & & $(0.0315)$ & & & & $(0.2291)$ & $(0.4637)$ & $(0.0545)$ & $(0.0590)$ \\
\hline & \multirow[t]{2}{*}{ Agricultural land } & 0.0118 & 0.00634 & $0.265^{* * *}$ & $0.275^{* *}$ & -0.0673 & 0.106 & $0.174 * * *$ & $0.142 * * *$ \\
\hline & & $(0.0473)$ & & & $(0.1220)$ & (0.1009) & $(0.1277)$ & $(0.0629)$ & $(0.0614)$ \\
\hline & Dwelling land & -0.0702 & 0.00477 & 0.0385 & 0.119 & -0.183 & 0.385 & 0.0844 & -0.128 \\
\hline \multirow{8}{*}{ 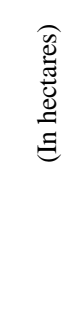 } & \multirow{4}{*}{$\begin{array}{l}\text { Non-cultivate } \\
\text { land }\end{array}$} & (0.0409) & $(0.0192)$ & $(0.0561)$ & $(0.1323)$ & $(0.2009)$ & (1.4773) & $(0.0911)$ & $(0.0111)$ \\
\hline & & 0.0596 & -0.0461 & 0.0412 & 0.0958 & $0.572^{*}$ & 0.166 & 0.0630 & 0.0229 \\
\hline & & & & & & & & & \\
\hline & & $(0.0500)$ & $(0.0216)$ & $(0.0403)$ & $(0.0384)$ & $(0.2205)$ & $(0.1480)$ & $(0.0620)$ & $(0.0866)$ \\
\hline & \multirow{2}{*}{ Constant } & $7.904 * * *$ & $5.648 * * *$ & $7.779 * * *$ & $5.033 * * *$ & $5.322 * * *$ & $8.775 * * *$ & $6.222 * * *$ & $4.547 * * *$ \\
\hline & & $(0.1460)$ & $(0.0831)$ & $(0.1531)$ & $(0.4145)$ & $(0.5839)$ & $(0.8200)$ & $(0.2287)$ & $(0.1895)$ \\
\hline & Observations & 3,364 & 3,344 & 3,359 & 2,316 & 285 & 198 & 2,196 & 3,123 \\
\hline & R-squared & 0.181 & 0.270 & 0.196 & 0.045 & 0.105 & 0.126 & 0.101 & 0.118 \\
\hline
\end{tabular}

Source: Authors' compilation based on HIES (2016).

Robust standard errors in the parentheses, *** $\mathrm{p}<0.01, * * \mathrm{p}<0.05, * \mathrm{p}<0$. 
In Model 1, the household that have migrants in the South-East Asian countries have lower expenditure compare to the households who have migrants in Middle-East countries. Meanwhile, households with migrants in countries of Africa, Europe, and Oceania have more expenditure than the base region. Therefore, the households who have migrants in those countries which are economically solvent are expending more money for their need fulfillment that ultimately portrays their economic welfare.

In Model 2 the data claims that households with the migrant member in East-Asian region, South-East Asia and North-America have 0.141 percent less food expenditure than that of Middle-East. Likewise, with the increase of one household member of the migrant family also increases the food expenditure with 1 percent level of significance which is expected. Besides, households living in rural areas have more food expenditure than urban households and it is statistically significant.

In the regression table, Model 7 and Model 8 represent that a one percent increase of monthly remittance increases the expenditure on both education and medical purpose by 0.0625 and 0.0736 percent respectively. After that, female household heads spend a significant amount of money on educational purpose compared to man headed household. The finding is consistent with Guzmán, Morrison and Sjöblom (2008). However, compare to Middle-East, Europe, North-America and Oceania holds an increasing amount of expenditure on education and medical purpose. Oceania has 1.47 percent and 1.28 percent more expenditure in those sectors than Middle-East. This might be the cause of spending more into educational and medical purposes as the economic condition of the households who send migrants to Europe, North America have better economic conditions that help them to expend more on education and health. This finding is also evident in literature, for instance, the study of Adams and Cuecuecha (2010) depicts that migration helps to increase the investment in human capital formation.

\section{b) Economic Welfare Assessment from the Dimension of wealth Index}

Along with the consumption expenditure authors consider wealth index as an indicator to access the economic welfare of the migrant sending household. It shows the economic welfare of the household of migrants considering wealth index amid four quantiles. Applying Principle Component Analysis technique a total of fifteen components of wealth are considered for wealth index formation through which is used as a dependent variable for further analysis. Basically, PCA constructs the score of wealth index which comprises 15 individual assets ownership of the households.

Table 5. Quantile regression of wealth index

\begin{tabular}{|c|c|c|c|c|}
\hline Explanatory Variables & $\begin{array}{l}\text { 1 }^{\text {st }} \text { Quantile } \\
25 \text { Percent } \\
\end{array}$ & $\begin{array}{l}2^{\text {nd }} \text { Quantile } \\
25 \text { Percent }\end{array}$ & $\begin{array}{l}3^{\text {rd }} \text { Quantile } \\
25 \text { Percent } \\
\end{array}$ & $\begin{array}{l}4^{\text {th }} \text { Quantile } \\
25 \text { Percent }\end{array}$ \\
\hline East-Asia & $\begin{array}{l}-0.347 \\
(0.382)\end{array}$ & $\begin{array}{l}-0.343 \\
(0.307)\end{array}$ & $\begin{array}{l}0.0803 \\
(0.0746)\end{array}$ & $\begin{array}{l}-0.657 \\
(0.477)\end{array}$ \\
\hline South-East Asia & $\begin{array}{l}-0.294 * * \\
(0.126)\end{array}$ & $\begin{array}{l}-0.183 * * \\
(0.0840)\end{array}$ & $\begin{array}{l}-0.116^{* *} \\
(0.0526)\end{array}$ & $\begin{array}{l}-0.249 * \\
(0.150)\end{array}$ \\
\hline Africa & $\begin{array}{l}1.163 * * * \\
(0.270)\end{array}$ & $\begin{array}{l}0.688^{* * * *} \\
(0.134)\end{array}$ & $\begin{array}{l}0.0696 \\
(0.0959)\end{array}$ & $\begin{array}{l}2.113 * * * \\
(0.429)\end{array}$ \\
\hline Europe & $\begin{array}{l}0.629 * * * \\
(0.176)\end{array}$ & $\begin{array}{l}0.264 * * \\
(0.128)\end{array}$ & $\begin{array}{l}0.176^{* * * *} \\
(0.0467)\end{array}$ & $\begin{array}{l}1.157 * * * \\
(0.267)\end{array}$ \\
\hline North-America & $\begin{array}{l}0.361 \\
(0.428)\end{array}$ & $\begin{array}{l}0.141 \\
(0.310)\end{array}$ & $\begin{array}{l}0.187 \\
(0.194)\end{array}$ & $\begin{array}{l}0.0971 \\
(1.253)\end{array}$ \\
\hline Oceania (Base=Middle-East) & $\begin{array}{l}1.171 * \\
(0.621)\end{array}$ & $\begin{array}{l}0.317 \\
(0.670)\end{array}$ & $\begin{array}{l}0.964 * * \\
(0.433)\end{array}$ & $\begin{array}{l}1.080 \\
(1.170)\end{array}$ \\
\hline Ln (Remittance Inflow) & $\begin{array}{l}0.183 * * * \\
(0.0493)\end{array}$ & $\begin{array}{l}0.131 * * * \\
(0.0269)\end{array}$ & $\begin{array}{l}0.0852 * * * \\
(0.0152)\end{array}$ & $\begin{array}{l}0.0729 \\
(0.0467)\end{array}$ \\
\hline Gender (Migrant) $($ Male $=1$, Female $=0$ ) & $\begin{array}{l}0.835^{*} \\
(0.468)\end{array}$ & $\begin{array}{l}0.431 * * \\
(0.208)\end{array}$ & $\begin{array}{l}0.593 * * * \\
(0.124)\end{array}$ & $\begin{array}{l}0.348 \\
(0.270)\end{array}$ \\
\hline Age (Migrant) & $\begin{array}{l}0.00522 \\
(0.00348)\end{array}$ & $\begin{array}{l}0.00457 * * \\
(0.00209)\end{array}$ & $\begin{array}{l}0.00611^{* * *} \\
(0.00215)\end{array}$ & $\begin{array}{l}0.00897 \\
(0.00707)\end{array}$ \\
\hline Gender $($ Head $)($ Male $=1$, Female $=0)$ & $\begin{array}{l}0.140 \\
(0.147)\end{array}$ & $\begin{array}{l}0.0283 \\
(0.0819)\end{array}$ & $\begin{array}{l}0.0524 \\
(0.0704)\end{array}$ & $\begin{array}{l}0.00980 \\
(0.204)\end{array}$ \\
\hline Schooling Years (Head) & $\begin{array}{l}0.0572 * * * \\
(0.0119)\end{array}$ & $\begin{array}{l}0.0366 * * * \\
(0.00779)\end{array}$ & $\begin{array}{l}0.0273^{* * *} \\
(0.00670)\end{array}$ & $\begin{array}{l}0.0826 * * * \\
(0.0191)\end{array}$ \\
\hline
\end{tabular}




\begin{tabular}{|c|c|c|c|c|}
\hline Explanatory Variables & $\begin{array}{l}1^{\text {st }} \text { Quantile } \\
25 \text { Percent }\end{array}$ & $\begin{array}{l}2^{\text {nd }} \text { Quantile } \\
25 \text { Percent }\end{array}$ & $\begin{array}{l}3^{\text {rd }} \text { Quantile } \\
25 \text { Percent }\end{array}$ & $\begin{array}{l}4^{\text {th }} \text { Quantile } \\
25 \text { Percent }\end{array}$ \\
\hline Earning Status $(\mathrm{Head})(\mathrm{Yes}=1, \mathrm{No}=0)$ & $\begin{array}{l}-0.479 * * * \\
(0.135)\end{array}$ & $\begin{array}{l}-0.280 * * * \\
(0.0795)\end{array}$ & $\begin{array}{l}-0.154 * * * \\
(0.0535)\end{array}$ & $\begin{array}{l}-0.471 * * \\
(0.204)\end{array}$ \\
\hline Household Size & $\begin{array}{l}0.0304 \\
(0.0222)\end{array}$ & $\begin{array}{l}0.0493 * * * \\
(0.0137)\end{array}$ & $\begin{array}{l}0.0282 * * * \\
(0.00985)\end{array}$ & $\begin{array}{l}-0.0169 \\
(0.0359)\end{array}$ \\
\hline Area $($ Rural $=1$, Urban $=0)$ & $\begin{array}{l}-0.749^{* * * *} \\
(0.104)\end{array}$ & $\begin{array}{l}-0.570 \text { *** } \\
(0.0642)\end{array}$ & $\begin{array}{l}-0.328 * * * \\
(0.0384)\end{array}$ & $\begin{array}{l}-0.992 * * * \\
(0.162)\end{array}$ \\
\hline Remittance Inflow (In times) & $\begin{array}{l}-0.188 \\
(0.238)\end{array}$ & $\begin{array}{l}-0.0889 \\
(0.138)\end{array}$ & $\begin{array}{l}-0.0361 \\
(0.112)\end{array}$ & $\begin{array}{l}0.525 \\
(0.321)\end{array}$ \\
\hline Duration of Migration & $\begin{array}{l}0.0353 * * * \\
(0.0120)\end{array}$ & $\begin{array}{l}0.0246 * * * \\
(0.00774)\end{array}$ & $\begin{array}{l}0.0194 * * * \\
(0.00605)\end{array}$ & $\begin{array}{l}0.0347 \\
(0.0233)\end{array}$ \\
\hline Constant & $\begin{array}{l}-3.058 * * * \\
(0.712)\end{array}$ & $\begin{array}{l}-1.345^{* * * *} \\
(0.348)\end{array}$ & $\begin{array}{l}-0.597 * * * \\
(0.140)\end{array}$ & $\begin{array}{l}-2.878^{* * * *} \\
(0.538)\end{array}$ \\
\hline Observations & 3,347 & 3,347 & 3,347 & 3,347 \\
\hline
\end{tabular}

Source: Authors' compilation based on HIES (2016).

Robust standard errors in the parentheses.

$* * * \mathrm{p}<0.01, * * \mathrm{p}<0.05, * \mathrm{p}<0.1$.

Table 5 describes the relationship of wealth score among the households with different destination preferences and other factors. It shows the wealth distribution of households considering four distinct quantiles. The outcome of the model predicts that household having migrants in South-East Asia has lower wealth status than that of Middle-East. Broadly, the household has 29.4 percent, 18.3 percent, 11.6 percent and 24.9 less wealth respectively along the lower to higher quantile and the result is statistically significant. Conversely, in every quantile, household having migrant in Europe has more wealth than Middle-East migrant-sending households. This gives the insight that the welfare of the household is better if the member migrates in European countries rather than Middle-Eastern countries. However, in the case of the migrant household who has migrant in South-East Asian countries has lower wealth score, i.e. low asset building capacity than household having migrant in Middle-Eastern countries. Additionally, Oceania has a significantly higher wealth score compare to Middle-East in the $3^{\text {rd }}$ quantile. Therefore, destination choice plays a crucial role in boosting household wealth scores, i.e. asset building capacity. Remittance inflow is a vital factor for this study where an increase in one percent of remittance inflow to the household, increases the wealth of the household in every quantile with one percent level of significance. Hence, in four quantile the wealth score increases for $1^{\text {st }}, 2^{\text {nd }}, 3^{\text {rd }}$, and $4^{\text {th }}$ quantile by 18.3, 13.1, 8.5 and 7.3 percent, respectively. This disparity is common since the household of lower quantile has more dependency on remittance than higher ones.

\section{c) Subjective Welfare}

Estimating and finding out the economic welfare never carries out the entire picture of the welfare of the household. In this section, the study has estimated an index of subjective welfare which consists of five factors related to subjective welfare. The model has been gone through the tests to detect Multicollinearity and Heteroscedasticity. Average Variance Inflation Factor (VIF) value is 1.26 which indicates no multicollinearity problem. On the other hand, White's test shows a $\mathrm{P}$ value less than 0.10 which measures Heteroscedasticity in the model. To fix up the problem, robust standard errors have been calculated in Table 6 .

Here, table 6 represents the results of the OLS regression model considering the subjective welfare of the household. The score of the index (outcome variable) ranges from ' 0 to 1 '. The result of the study indicates that one 1 percent increase of monthly income increases the subjective welfare by 0.66 percent keeping other things constant which shows income brings happiness to the households. Meanwhile, subjective welfare score declines with an additional new household member (significant in 1 percent level). The more household member, the more expenditure required to live that makes life difficult.

The outcome of the model also exhibits that household of the rural area tend to have 0.0104 higher score for the subjective welfare index with 10 percent significance than urban household. This can be relatable as people living in urban area have a worse environment to live and also have to experiance different social and economic challenges. But the rural people stay happy in tiny things. Table 6 also provides results for the region variable in categorical form. Other things remaining constant, household related to South-East Asia have 0.022 less subjective welfare score (5 percent significance) but North-America have 0.092 more score than that of Middle-East migrant-sending household. Hence, this can be interpreted that choosing North-America as the 
migration destination helps the household to be happy than others and it has also a positive indication to Oceania.

Table 6. OLS regression model of subjective welfare

\begin{tabular}{|c|c|}
\hline Explanatory Variable & Subjective Welfare \\
\hline \multirow{2}{*}{$\operatorname{Ln}($ Income $)$} & $0.00658^{*}$ \\
\hline & $(0.0048)$ \\
\hline \multirow{2}{*}{ Household size } & $-0.0141 * * *$ \\
\hline & $(0.0020)$ \\
\hline \multirow{2}{*}{ Area (Rural=1,Urban=0) } & $0.0104 *$ \\
\hline & $(0.0097)$ \\
\hline \multirow{2}{*}{ Earner Head $(\mathrm{Yes}=1, \mathrm{No}=0)$} & 0.00129 \\
\hline & $(0.0112)$ \\
\hline \multirow{2}{*}{ Gender $($ Head $)($ Male $=1$, Female $=0)$} & -0.00226 \\
\hline & $(0.0116)$ \\
\hline \multirow{2}{*}{ East-Asia } & $-0.0474 *$ \\
\hline & $(0.0205)$ \\
\hline \multirow{2}{*}{ South-East Asia } & $-0.0222 * *$ \\
\hline & $(0.0099)$ \\
\hline \multirow{8}{*}{ 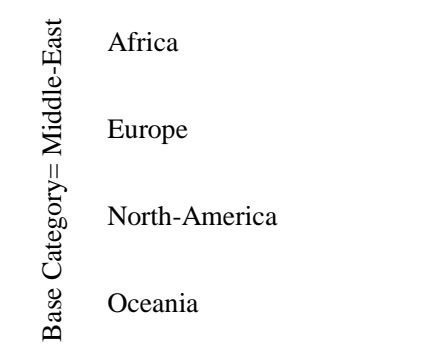 } & 0.0406 \\
\hline & $(0.0397)$ \\
\hline & 0.00571 \\
\hline & $(0.0146)$ \\
\hline & $0.0919 * *$ \\
\hline & $(0.0514)$ \\
\hline & 0.109 \\
\hline & $(0.0526)$ \\
\hline \multirow{2}{*}{ Ln (Food Expense) } & -0.00591 \\
\hline & $(0.0080)$ \\
\hline \multirow{2}{*}{ Ln (Education Expense) } & $0.0131 * * *$ \\
\hline & $(0.0039)$ \\
\hline \multirow{2}{*}{ Ln (Medical Expense) } & $0.00976 * * *$ \\
\hline & $(0.0031)$ \\
\hline \multirow{2}{*}{ Operative Land (Hectares) } & -0.000929 \\
\hline & $(0.0010)$ \\
\hline \multirow{2}{*}{ Remittance inflow (In times) } & $0.0569 * * *$ \\
\hline & $(0.0010)$ \\
\hline \multirow{2}{*}{ Constant } & $0.292 * * *$ \\
\hline & $(0.0202)$ \\
\hline Observations & 3,118 \\
\hline $\mathrm{R}$-squared & 0.058 \\
\hline
\end{tabular}

Again an one percent increase of educational expense of the household increases the subjective welfare by 1.31 percent by holding other issue constant which has 1 percent level of statistical significance. Medical expenditure associates with this result by increasing the subjective welfare by 0.976 percent at one percent significance level. Having good health and adequate educational attainment, household pursue happy life more likely. This may also add that the educational expense is an investment on making human capital which will provide earnings to the household and it ultimately brings positive mental health and wealth.

Lastly, if the migrant send remittance one more time, the subjective welfare also increases of the household with 0.0569 score, other things remaining constant. If we focus on human psychology, getting remittance more times definitely makes the household member cheerful and tension free. If the migrant does not send remittance 
frequently, this might lead to the negative impact on subjective welfare of the migrant household. Therefore, the household's subjective welfare significantly increases and decreases for many reasons. Besides, there is also significant subjective welfare differences among the households for the deviation of choice or preference of migration destination.

\section{Main Findings}

An overview of the result of Multinomial Logistic Regression reveals that migrant's age, gender, schooling years along with head age and household size, origin, and land ownership impact significantly on the destination preference of migrants. It is found that the increasing age of migrant makes less probability to choose to migrate in East-Asia and South-East Asia but more probability to migrate in North-America than Middle-East. Whereas, if the schooling year increases of the migrant then the probability of migrating Africa is 0.0021 percent more, for Europe it is 0.0107 more, 0.0028 percent more for North-America and 0.0010 percent more for Oceania than Middle-East with 1 percent significance. This result also complies with the study of (Regmi, 2014). Moreover, the increasing number of household size decreases the probability of migrating in South-East Asian countries than countries of Middle-East. Besides, earning status of the head also has an impact on the decision of choosing a migration destination. It is revealed that head who earns have more probability to send a family member to South-East Asia but less likely to send Europe than Middle-East compared to the non-earner head. This is because the non-earner head decides to send members in those countries which have easy and less costly access to enter. Definitely, Europe has more accessibility than North-America.

Versatile expenditure segments have been taken to analyze the economic welfare of the household. It is observed that household who send migrant to South-East Asia and North-America spend less in food sector rather than Middle-East but household who send migrant in Africa spends in food 0.346 percent more than Middle-East. However, in the non-food sector, household have more spending for Europe and Oceania than Middle-East. Household spends more on durable goods who send their members in East-Asia and South-East Asia but the expenditure is less for Oceania than Middle-East. Education and Medical expenditure also express expected results for the region. Particularly, households who have a migrant member in Europe, North-America, and Oceania spend more on education and medical purpose than households who have migrant in Middle-East. It indicates that these households have economic welfare since they have the ability to spend in these sectors which represent better life standard.

The study again estimated the wealth index to measure the economic welfare in four quartiles of the household. It is found that wealth score is less in every quantile for South-East Asia than Middle-East. It denotes that household sending their members to the county like Singapore, Malaysia has less economic welfare than household who has migrants in Saudi Arabia, Qatar etc. Furthermore, the wealth score is higher for the household who sends migrant in Europe, North-America, Oceania than that of Middle-East. The study also endeavoured to measure the subjective welfare of the household regarding destination preference. It is unveiled that the subjective welfare of the household who sends migrant in East-Asia and South-Asia are lower than those of Middle-East. Hence, it is better to migrate in Middle-East than countries like Iran, Iraq, Singapore etc. But to migrate in North-America has more subjective welfare to the migrant-sending household than Middle-East. Additionally, the more the migrants send remittance the more subjective welfare gained by the households. Household income also has similar results for the subjective welfare of the households.

\section{Conclusion}

The study mainly deals with secondary data of HIES 2016, Bangladesh to analysis the factors affecting destination preference of international migrants of Bangladesh and it's ultimate aftermath on the household welfare. The results showed various significant factors like age, sex, education of migrants and household head, origin and other household characteristics that trigger the decision to choose versatile destinations of migration. The study not just revealed the factors but also captured the whole welfare scenario of the household. It can be concluded that the household with diverse destination preference certainly makes variation of both economic and subjective welfare. Hence, the household's ability to spend and being happy also depends on the region they send members for earning. If it is possible to conduct baseline survey and then collect date further after migration then the impact of international migration can be figure out with better precision which is beyond the scope of the study. Addressing this aspect as a research gap, experts in this field are highly encouraged to contribute in the field of existing literature.

\section{References}

Adams Jr, R. H. (1991). The Economic Uses and Impact of International Remittances in Rural Egypt. Economic Development and Cultural Change, 39(4), 695-722. https://doi.org/10.1086/451904 
Adams Jr, R. H., \& Cuecuecha, A. (2010). Remittances, Household Expenditure and Investment in Guatemala. World Development, 38(11), 1626-1641. https://doi.org/10.1016/j.worlddev.2010.03.003

Ahmed, M. S. (2010). Migrant Workers Remittance and Economic Growth: Evidence from Bangladesh. ASA University Review, 4(1), 1-13.

Amit, K., \& Riss, I. (2014). The Subjective Well-being of Immigrants: Pre-and Post-migration.Social Indicators Research, 119(1), 247-264. https://doi.org/10.1007/s11205-013-0492-7

Barai, M. K. (2012). Development Dynamics of Remittances in Bangladesh. Sage Open, 2(1), 1-13. https://doi.org/10.1177\%2F2158244012439073

Betz, W., \& Simpson, N. B. (2013). The Effects of International Migration on the Well-being of Native Populations in Europe. IZA Journal of Migration, 2(1), 12. https://doi.org/10.1186/2193-9039-2-12

Chakraborty, D., \& Kuri, P. K. (2017). The Household Level Determinants in the Choice and Level of Migration: A Micro Study in West Bengal. Environment and Urbanization ASIA, 8(1), 94-104.https://doi.org/10.1177\%2F0975425316683864

Chasekwa, B., Maluccio, J. A., ... , \& Tielsch, J. M. (2018). Measuring Wealth in Rural Communities: Lessons from the Sanitation, Hygiene, Infant Nutrition Efficacy (SHINE) trial. PloS One, 13(6). https://doi.org/10.1371/journal.pone.0199393

De Brauw, A., Mueller, V., \& Woldehanna, T. (2013). Does Internal Migration Improve Overall Well-being in Ethiopia? Working Paper, No-55, Ethiopia Strategy Support Program II, Africa. https://doi.org/10.1093/jae/ejx026

Du, Y., Park, A., \& Wang, S. (2005). Migration and Rural Poverty in China. Journal of Comparative Economics, 33(4), 688-709. https://doi.org/10.1016/j.jce.2005.09.001

Fafchamps, M., \& Shilpi, F. (2008). Determinants of Choice of Migration Destination. Working Paper, No. 2009-09, The World Bank. https://doi.org/10.1596/1813-9450-4728.

Ferrer-i-Carbonell, A., \& Van Praag, B.M. (2002). The subjective costs of health losses due to chronic diseases. An alternative model for monetary appraisal.Health Economics,11(8), $709-722$. https://doi.org/10.1002/hec.696

Friedberg, R. M. (2001). The Impact of Mass Migration on the Israeli Labor Market. The Quarterly Journal of Economics, 116(4), 1373-1408. https://doi.org/10.1162/003355301753265606

Greenwood, M. J. (1975). Research on Internal Migration in the United States: A Survey. Journal of Economic Literature, 397-433.

Greve, B. (2008). What is Welfare? Central European Journal of Public Policy, 2(1), 50-73.

Guzmán, J. C., Morrison, A. R., \& Sjöblom, M. (2008). The impact of remittances and gender on household expenditure patterns: Evidence from Ghana. The International Migration of Women, 125-152.

IOM. (2017). Bangladesh Annual Migration Report 2017 (1st ed., p. 56). International Organization for Migration, Bangladesh.

Koenker, R., \& Regression, Q. (2005). Confidence Intervals for Regression Quantiles, Asymptotic Statistics (pp. 349-359). New York: Cambridge University Press.

Koenker, R., \& Regression, Q. (2005). New York: Cambridge University Press.

Lozano, F. A., \& Steinberger, M. D. (2012). Empirical methods in the economics of international immigration. Handbook of Research Methods in Migration, 163-185.

Lozano, F. A., \& Steinberger, M. D. (2012). Handbook of Research Methods in Migration: Empirical Methods in the Economics of International Immigration (pp. 163-185). Edward Elgar Publishing Limited, The Lypiatts, 15 Landsdown Road, Cheltenham, Glos GL50 2JA, UK.

Mahmud, H. (2016). Impact of the destination state on migrants' remittances: A study of remitting among Bangladeshi migrants in the USA, the UAE and Japan. Migration and Development, 5(1), 79-98. https://doi.org/10.1080/21632324.2015.1022007

Mahmud, H. (2016). Impact of the Destination State on Migrants' Remittances: A Study of Remitting among Bangladeshi Migrants in the USA, the UAE and Japan. Migration and Development, 5(1), 79-98.https://doi.org/10.1080/21632324.2015.1022007 
Milewska, A. J., Jankowska, D., Więsak, T., Acacio, B., \& Milewski, R. (2017). The application of multinomial logistic regression models for the assessment of parameters of oocytes and embryos quality in predicting pregnancy and miscarriage. Studies in Logic, Grammar and Rhetoric, 51(1), 7-18. https://doi.org/10.1515/slgr-2017-0030

Mora, J., \& Taylor, J. E. (2006). Determinants of migration, destination, and sector choice: Disentangling individual, household, and community effects. International Migration, Remittances, and the Brain Drain, 21-52.

Mora, J., \& Taylor, J. E. (2006). Determinants of Migration, Destination, and Sector Choice: Disentangling Individual, Household, and Community Effects. International Migration, Remittances, and the Brain Drain (pp. 21-52). The World Bank and Palgrave Mcmillan.

Orozco, M. (2010). Migration, Remittances and Assets in Bangladesh: Considerations About Their Intersection and Development Policy Recommendations. International Organization of Migration.

Pellegrini, P. A., \& Fotheringham, A. S. (2002). Modelling spatial choice: A review and synthesis in a migration context. Progress in Human Geography, 26(4), 487-510. https://doi.org/10.1191/0309132502ph382ra

Pellegrini, P. A., \& Fotheringham, A. S. (2002). Modelling Spatial Choice: A Review and Synthesis in a Migration Context. Progress in Human Geography, 26(4), 487-510. https://doi.org/10.1191\%2F0309132502ph382ra

Penninx, R., Schoorl, J. J., \& van Praag, C. S. (1993). The Impact of International Migration on Receiving Countries: The Case of the Netherlands (28th ed.). Swets \& Zeitlinger, Lisse.

Pfau, W. D., \& Giang, L. T. (2009). Determinants and impacts of international remittances on household welfare in Vietnam. International Social Science Journal, 60(197-198), 431-443. https://doi.org/10.1111/j.1468-2451.2010.01733.x

Pfau, W. D., \& Giang, L. T. (2009). Determinants and impacts of international remittances on household welfare in Vietnam. International Social Science Journal, 60(197-198), 431-443. https://doi.org/10.1111/j.1468-2451.2010.01733.x

Raihan, S., Sugiyarto, G., Bazlul, H. K., \& Jha, S. (2009). Remittances and Household Welfare: A Case Study of Bangladesh. Working Paper, No. 189, Asian Development Bank Economics. https://dx.doi.org/10.2139/ssrn.1618142

Regmi, M. (2014). Three essays on migration decision, migration destination choice, and food security: Evidence from Chitwan, Nepal.

Regmi, M. (2014). Three Essays on Migration Decision, Migration Destination Choice, and Food Security: Evidence from Chitwan, Nepal. Unpublished Master's Thesis, The Department of Agricultural Economics and Agribusiness, Louisiana State University and Agricultural and Mechanical College, Baton Rouge, Louisiana, US.

Schiff, M., \& Özden, Ç. (2005). International Migration, Remittances, and The Brain Drain. The World Bank and Palgrave Mcmillan. https://doi.org/10.1596/978-0-8213-6372-0

Schyns, P. (2001). Income and Satisfaction in Russia.Journal of Happiness Studies, 2(2), 173-204. https://doi.org/10.1023/A:1011564631319

Serino, M. N. V., \& Kim, D. (2011). How do international remittances affect poverty in developing countries? A quantile regression analysis. Journal of economic Development, 36(4), 17-25. https://doi.org/10.35866/caujed.2011.36.4.002

Serino, M. N. V., \& Kim, D. (2011). How Do International Remittances Affect Poverty in Developing Countries? A Quantile Regression Analysis. Journal of Economic Development, 36(4), 17. https://doi.org/10.35866/caujed.2011.36.4.002

Siddiqui, T. (2003). Migration as a Livelihood Strategy of the Poor: The Bangladesh Case. Dhaka: The University Press Limited.

Viet Cuong, N., \& Mont, D. (2012). Economic Impacts of International Migration and Remittances on Household Welfare in Vietnam. International Journal of Development Issues, 11(2), 144-163. https://doi.org/10.1108/14468951211241137

Zorlu, A., \& Mulder, C. H. (2010). Location Choices of Migrant Nest-leavers: Spatial Assimilation or Continued 
Segregation? Advances in Life Course Research, 15(2-3), 109-120. https://doi.org/10.1016/j.alcr.2010.06.001

\section{Appendix A}

Table A1. Region segregation

\begin{tabular}{|c|c|c|c|c|c|c|}
\hline East Asia & South-East Asia & Africa & Middle-East & Europe & Oceania & North-America \\
\hline Iran & Malaysia & $\begin{array}{l}\text { South } \\
\text { Africa }\end{array}$ & Saudi Arabia & U.K. & Australia & USA \\
\hline Iraq & Singapore & & Qatar & Germany & & Canada \\
\hline Japan & Brunei & & Kuwait & Italy & & \\
\hline Korea (South) & & & Oman & Other European Country & & \\
\hline Libya & & & United Arab Emirates & Sweden & & \\
\hline Turkey & & & & Mauritius & & \\
\hline
\end{tabular}

\section{Copyrights}

Copyright for this article is retained by the author(s), with first publication rights granted to the journal.

This is an open-access article distributed under the terms and conditions of the Creative Commons Attribution license (http://creativecommons.org/licenses/by/4.0/). 